\title{
A new species of Macrostemum Kolenati, 1859 from Brazilian Amazon and the immature stages of $M$. brasiliense (Fischer, 1970) (Trichoptera: Hydropsychidae)
}

\author{
Ana M. PES ${ }^{1, *}$, Gleison R. DESIDÉRIO², \\ Patrik BARCELOS-SILVA ${ }^{3} \&$ Neusa HAMADA ${ }^{4}$ \\ 1,2,3,4 Instituto Nacional de Pesquisas da Amazônia (INPA), Coordenação de Biodiversidade (CoBio), \\ Programa de Pós-graduação em Entomologia (PPG-Ent), Manaus, Amazonas, Brazil. \\ "Corresponding author: anampes@gmail.com \\ 2Email: gleysonbio@gmail.com \\ ${ }^{3}$ Email: patrikbarcelos@gmail.com \\ ${ }^{4}$ Email: neusaha@gmail.com \\ ${ }^{1}$ https://orcid.org/0000-0003-0901-5965 \\ ${ }^{2} \mathrm{https}: / /$ orcid.org/0000-0002-5048-9786 \\ ${ }^{4} \mathrm{https}: / /$ orcid.org/0000-0002-3526-5426
${ }^{1}$ urn:1sid:zoobank.org:author:03D29AFD-A7EE-49DA-9740-7FA0F34932AF
${ }^{2}$ urn:1sid:zoobank.org:author:63EE23DE-6125-4167-A3AA-27E2A982928
${ }^{3}$ urn:1sid:zoobank.org:author:BFE5C5B5-97A2-4CBB-8133-9737579F12D2
${ }^{4}$ urn:1sid:zoobank.org:author:0D02F36C-6B09-423C-95A6-6179E9808CD5

\begin{abstract}
Macrostemum is the second largest genus of Macronematinae with about 104 described species distributed in the Neotropical (18), Afrotropical (20), Australasian (7), Palearctic (2), Nearctic (3) and Oriental (54) regions. Despite its great diversity, knowledge about its immature stages is scarce: worldwide, only 7 species $(6.7 \%)$ have larvae and/or pupae described. From the Neotropics, only one species, Macrostemum ulmeri (Banks, 1913), has described larvae and pupae. The objectives of this study are to describe and illustrate a new species, Macrostemum araca sp. nov., based on adult males and females from Serra do Aracá, Amazonas, Brazil, and the larvae and pupae of M. brasiliense (Fischer, 1970) from an Atlantic Forest fragment in São Paulo state using the metamorphotype method. In addition, this species is recorded for the first time for Minas Gerais state.
\end{abstract}

Keywords. Aquatic insect, larva, pupa, taxonomy, Neotropical, Serra do Aracá, Atlantic Forest.

Pes A.M., Desidério G.R, Barcelos-Silva P. \& Hamada N. 2019. A new species of Macrostemum Kolenati, 1859 from Brazilian Amazon and the immature stages of M. brasiliense (Fischer, 1970) (Trichoptera: Hydropsychidae). European Journal of Taxonomy 534: 1-20. https://doi.org/10.5852/ejt.2019.534 


\section{Introduction}

Macrostemum Kolenati, 1859 is a typical Macronematinae genus recorded in all biogeographical regions except Antarctica. The Oriental region is the most diverse, with about 54 species, followed by Afrotropical (20 species), Neotropical (18 species), and Australian ( 7 species) regions, while in the entire Holarctic region only 5 species have been recorded. Macrostemum, with more than 100 species, is one of the largest genera of Macronematinae, being only surpassed by Leptonema Guérin-Méneville, 1843, which has about 150 species (Morse 2019).

Adults are easily recognized by the color pattern of their wings, with membrane strongly marked with contrasting dark and light colors. As the species have very similar genital structures, the color pattern is important for species identification. Larvae build small tubes of sand in which they weave complex retreat nets to capture very fine particles from the water flow (Holzenthal \& Calor 2017).

Knowledge of the immature stages in the genus is very scarce: only seven species $(6.7 \%)$ have larvae and/or pupae described (Ross 1944; Sattler 1963, 1968; Marlier 1964; Lepneva 1970; Flint \& BuenoSoria 1982; Scott 1983; Wiggins 1996; Ogbogu \& Adu 2006). Only one species from the Neotropics, M. ulmeri (Banks, 1913), has described larva and pupa and biological information, such as caseconstruction behavior and diet (Sattler 1963, 1968). Marlier (1964) also described larvae and pupae of this species, but under the name Macronema siolii Marlier, 1964, synonymized by Flint (1978).

Neotropical Macrostemum were revised by França et al. (2013), and a new species was described by Oláh \& Johanson (2012), but these studies did not formally describe any larvae. Currently, according to Holzenthal \& Calor (2017), the following species are recorded for the Neotropical region: Macrostemum arcuatum (Erichson, 1848), M. brasiliense (Fischer, 1970), M. braueri (Banks, 1924), M. bravoi Franca, Paprocki \& Calor, 2013, M. digramma (McLachlan, 1871), M. erichsoni (Banks, 1920), M. felker Oláh \& Johanson, 2012, M. hyalinum (Pictet, 1836), M. negrense Flint, 1978, M. nigrum Franca, Paprocki \& Calor, 2013, M. par (Navás, 1930), M. ramosum (Navás, 1916), M. santaeritae (Ulmer, 1905), M. subaequale (Banks, 1920), M. surinamense (Flint, 1974), M. trigramma (Navás, 1916), M. triste (Navás, 1916), and M. ulmeri.

In this study we describe and illustrate a new species of Macrostemum based on adult males and females from Serra do Aracá, Amazonas state, Brazil. Additionally, description of immature stages of M. brasiliense collected at Atlantic Forest, São Paulo state, Brazil, are also provided, including new distributional records and bionomic information.

\section{Material and methods}

Adults were collected using Pennsylvania light trap and Malaise flight interception traps or manually with a net. Larvae and pupae were collected directly from the substrates (stones and macrophytes), with the aid of forceps, in moderate to fast-flowing water zones of low-order streams. The immatures and some adults were preserved in $80 \%$ and $96 \%$ ethanol; other adults were pinned as indicated in the 'Material examined' section.

In order to observe male and female genital structures, the abdomen of each specimen was removed and cleared in $10 \% \mathrm{KOH}$ heated to $125^{\circ} \mathrm{C}$ for $40 \mathrm{~min}$. After clearing, the abdomen was washed in distilled water and was then placed for few minutes in a solution of $50 \%$ glacial acetic acid $50 \%$ ethanol to neutralize the $\mathrm{KOH}$, mounted with glycerin on a temporary slide and examined with a Leica DM5500 B compound microscope; it was then permanently stored in glycerin in a microvial, with the remainder of the respective specimen stored in a plastic vial with ethanol. The head, labrum, mandibles and legs of the larva were dissected for use in illustrations and were subsequently stored in a vial with $80 \%$ ethanol. Pupae were preserved in vials with $80 \%$ ethanol. 
Photographs of larvae, pupae, and adults were obtained with a Leica DFC 420 video camera attached to a Leica M165C stereomicroscope using a LED illumination dome to reduce light reflection on the specimens (Kawada \& Buffington 2016). Stacks of images of each structure were produced at different focal distances; these images were combined automatically into a single image with a greater depth of field using Helicon Focus ${ }^{\circledR}$ (version 6.8.0 Pro) software. Stacked images of the genitalia were taken with an Olympus DP72 video camera attached to an Olympus BX51 compound microscope and then used as templates to create graphic vectors.

Larvae and pupae of $M$. brasiliense were associated with the male adult using the metamorphotype method (Milne 1938; Wiggins 1996). Morphological terminology follows França et al. (2013) for the male adult, Hoang et al. (2005) for the female adult, and Flint \& Wallace (1980), Scott (1983) and Wiggins (1996) for larval and pupal characters. The nomenclature for chaetotaxy of the larval primary setae is that of Williams \& Wiggins (1981); for the secondary setae it is that of Schefter \& Wiggins (1986).

The map showing the collection sites was created using DIVA-GIS version 7.5 free software. Lists of material examined were made using the AUTOMATEX macro in Microsoft Excel (Brown 2013).

Types and all other examined specimens are deposited in the Coleção de Invertebrados, Instituto Nacional de Pesquisas da Amazônia (INPA), Manaus, Amazonas, Brazil.

\section{Abbreviations of genital structures}

$\begin{array}{ll}\mathrm{As} & =\text { anterior sclerite } \\ \mathrm{Asi} & =\text { apical segment of the inferior appendage } \\ \mathrm{Bs} & =\text { basal segment of the inferior appendage } \\ \mathrm{Ce} & =\text { cercus } \\ \mathrm{Dcp} & =\text { dorsal cap } \\ \mathrm{Lv} & =\text { lateral valve } \\ \mathrm{PaD} & =\text { dorsal papillae } \\ \mathrm{PaV} & =\text { ventral papillae } \\ \mathrm{Ph} & =\text { phallotrema } \\ \mathrm{PoS} & =\text { posterior sclerite } \\ \mathrm{Ps} & =\text { phallotremal sclerite } \\ \mathrm{Rc} & =\text { receptacle } \\ \mathrm{Se} & =\text { segment } \\ \mathrm{St} & =\text { sternum } \\ \mathrm{Te} & =\text { tergum } \\ \mathrm{Vo} & =\text { vaginal opening } \\ \mathrm{Vt} \mathrm{pl} & =\text { ventral plate of abdominal sternum VIII }\end{array}$

\section{Institutional abbreviations}

INPA = Instituto Nacional de Pesquisas da Amazonia, Manaus, Brazil

NMW $=$ Naturhistorisches Museum, Vienna, Austria

ZSM = Zoologischen Staatssamlung München, Munich, Germany 


\title{
Results
}

\author{
Class Insecta Linnaeus, 1758 \\ Order Trichoptera Kirby, 1813 \\ Suborder Annulipalpia Martynov, 1924 \\ Superfamily Hydropsychoidea Curtis, 1835 \\ Family Hydropsychidae Curtis, 1835 \\ Genus Macrostemum Kolenati, 1859 \\ Macrostemum araca sp. nov. \\ urn:lsid:zoobank.org:act:054F8F36-D216-4B3C-922E-EAA97C032676
}

Figs $1-5$

\section{Diagnosis}

Macrostemum araca sp. nov. male is similar to M. braueri and M. surinamense males by having phallus apex with long posterolateral and acuminate prominence, but it can be distinguished from these species by the shape and number of setae on tergite IX with 20 long dorsal setae and 9 lateral setae, while $M$. braueri has 7 long dorsal setae and 7 lateral setae and M. surinamense has 15 long dorsal setae and 8 lateral setae. Additionally, the color pattern of forewing in the new species is yellow with 2 darkbrown vertical bands on the distal half, the apical $1 / 3$ is dark brown with an elongated median hyaline spot, while in $M$. braueri the forewing is mostly hyaline, each with one dark band bordering apical area and delimiting one boot-shaped hyaline area, and in M. surinamense the forewing is dark-brown with only two small hyaline bands in apical area.

The female of Macrostemum araca sp. nov. can be recognized by the sternum VIII divided almost completely along the midline into two oval plates and tergum IX with a row of long setae on the posterior margin dorsally.

\section{Etymology}

The specific epithet is a noun in apposition that refers to the Serra do Aracá mountain range, which is the type-locality of the new species.

\section{Material examined}

Holotype

BRAZIL: - ${ }^{\Uparrow}$; Amazonas, Barcelos, Parque Estadual Serra do Aracá, Igarapé da Cobra no Acampamento (\#B01); 0052'24.78" N, 63²7'18.97" W; alt. 136 m; 30 Jul.-2 Aug. 2009; A.P.M. Santos, J.O. Silva, J.L. Nessimian, N. Ferreira Jr., U.G. Neiss and F.F. Salles leg.; INPA.

\section{Paratypes}

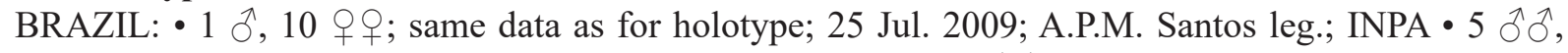

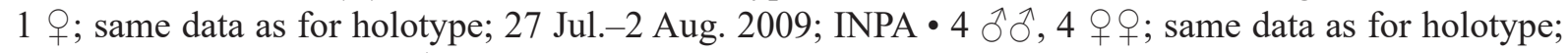
4-5 Aug. 2009; INPA • 1 Ō, 2 q 9 ; same data as for holotype; Igarapé do Jabuti (\#B07); 0052'47.78"

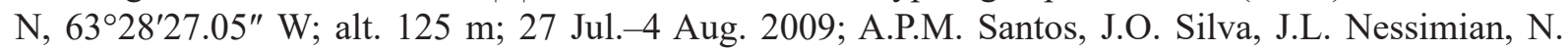
Ferreira Jr., U.G. Neiss and F.F. Salles leg.; INPA $2 \hat{\partial} \hat{\partial}, 1$ क ; same data as for holotype; Igarapé da

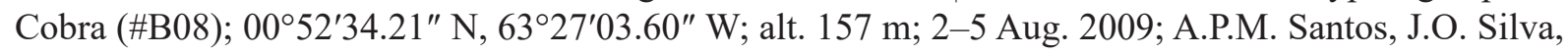
J.L. Nessimian, N. Ferreira Jr., U.G. Neiss and F.F. Salles leg.; INPA • 1 क ; same data as for holotype; Comunidade Serrinha, Rio Aracá; 00²5'25.8” N, 63²3'47.0" W; alt. 69 m; 28 Jul.-6 Aug. 2009; N. Hamada, A.M. Pes, R.L.F. Keppler, C.A.S. Azevedo and C. Monteiro leg.; INPA • 1 q; Barcelos, [neighboring the] Serra do Aracá; 0052'24" N, 6327'19" W; alt. 149 m; Jul.-Aug. 2007; A. Filho leg.; INPA. 

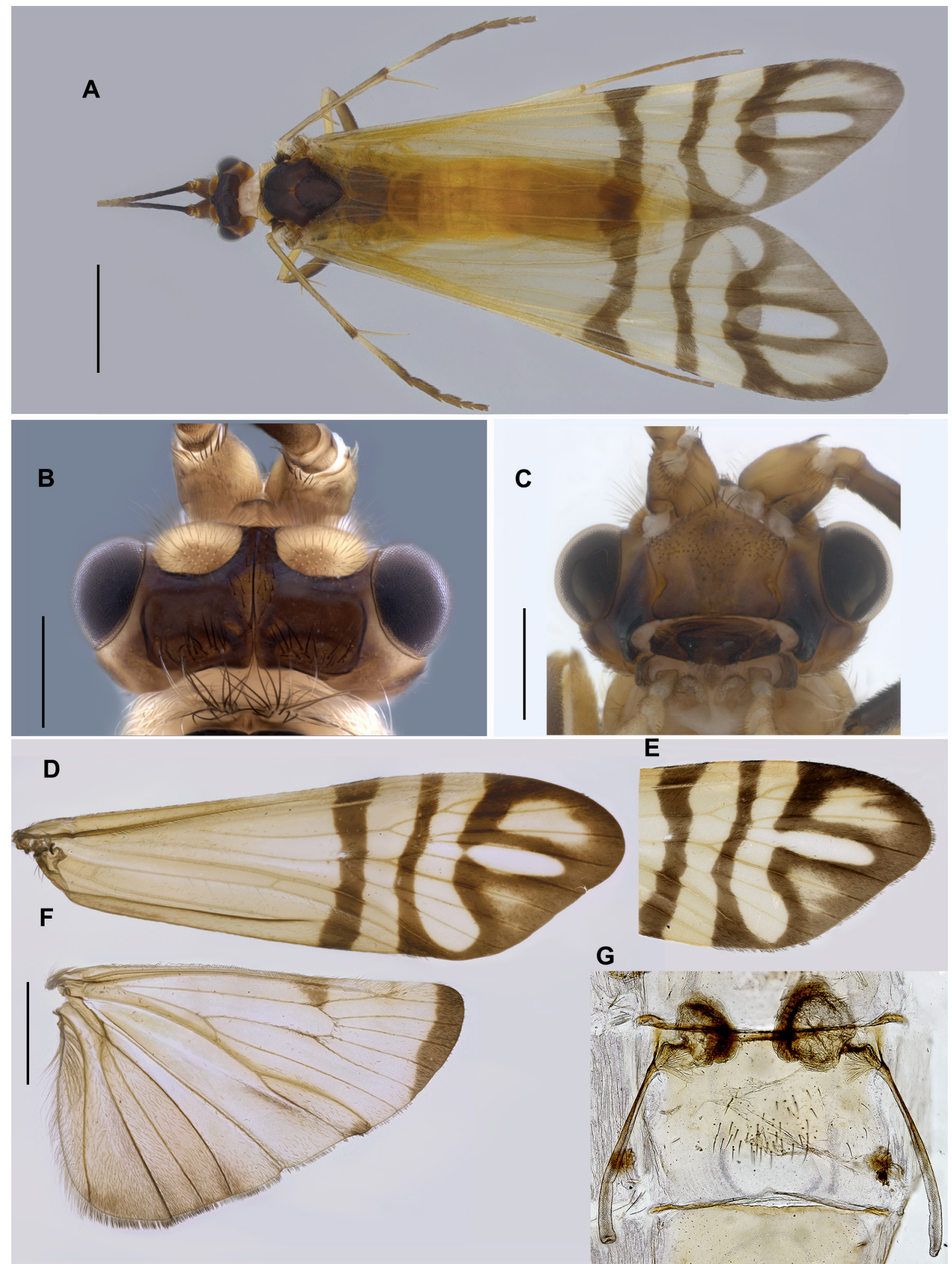

Fig. 1. Macrostemum araca sp. nov., adult male. A. Dorsal habitus. B-C. Head, dorsal and frontal views. D. Forewing (holotype). E. Forewing, variation in the apical area (paratype). F. Hindwing (holotype). G. Process of sternite V. Scale bars: A, D-F $=2 \mathrm{~mm}$; B-C $=0.5 \mathrm{~mm}$. 


\section{Description}

Adult male (Figs 1A-G, 2A-B)

Length of forewing: $10.91-12.69 \mathrm{~mm}$ (mean $=10.42 \mathrm{~mm}, \mathrm{SD}=0.59, \mathrm{n}=9$ ).

General color dark-brown and golden-yellow (in alcohol) (Fig. 1A-F). Antennae basal 1/3 (approximately) dark-brown, apical region yellow; scape $2 \times$ longer than wide, with base slightly enlarged; pedicel short and broad. Head and setae dark-brown with some dark setae and anterior setal wart pale-yellow, covered with yellow setae, posterior setal wart brown, covered with brown setae, palps and haustellum paleyellow (Fig. 1B-C). Thorax, pronotum yellow covered with pale-yellow setae, meso- and metanotum dark-brown covered with brown setae; foreleg tibia and tarsus brown, mid and hind legs coxae and femora light-brown to yellow. Tibial spur formula 2,4,4. Midleg tarsus flattened. Forewing completely golden-yellow in basal region, with basal half without bands or spots, distal half with two vertical brown bands, the apical $1 \frac{1}{3}$ is golden-brown with an elongated hyaline spot between veins R5 - M1 (may be open in the anterior region, Figs 1E, 2A) with light spots above and below (variable from pale-yellow to light-brown until almost imperceptible), entire wing covered with fine setae, light-brown (in alcohol) (Fig. 1D-E); veins Sc and R1 fused near apex, forks I-V present, forks I and IV petiolate; discoidal cell small, median cell moderately in size, thyridial cell very long. Nygma and thyridium present. Hindwing almost totally golden-yellow, only with a small dark-brown triangle medially and a dark-brown band in the apical area; anal area large, veins Sc thickened and contiguous with R1 near apex; fork II, III and V present, fork $\mathrm{V}$ petiolate, discoidal and median cell absent, nygma present, veins between $\mathrm{Cu}$ and $\mathrm{A}$ vein anastomosed (Figs 1F, 2B). Sternum V, with long anterolateral glandular processes, $1.2 \times$ longer than sternums V and VI, with basal opening and reticulated filament (Fig. 1G).

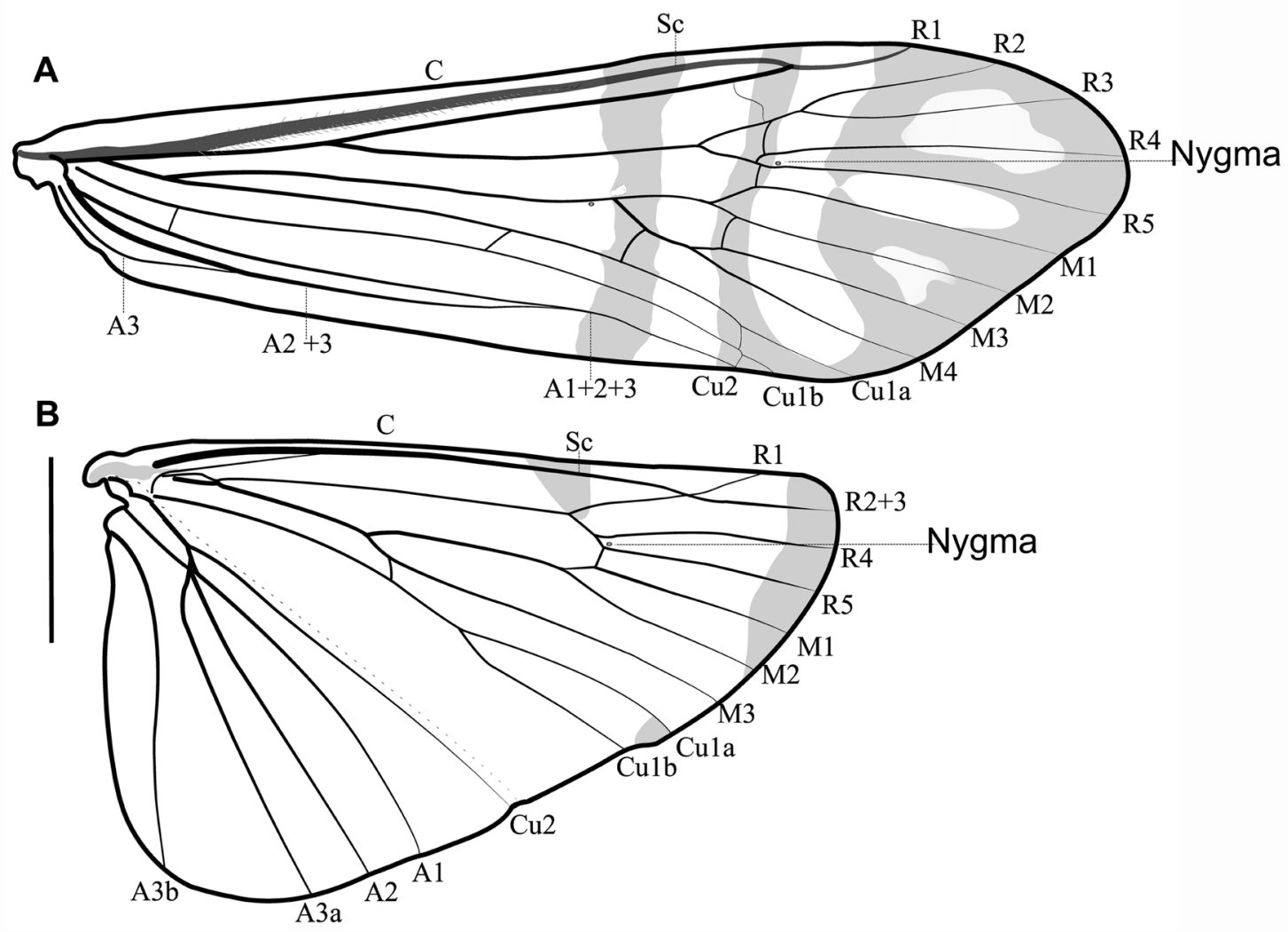

Fig. 2. Macrostemum araca sp. nov., adult male. A. Venation of the forewing (holotype). B. Venation of the hindwing (holotype). Scale bar $=2 \mathrm{~mm}$. 

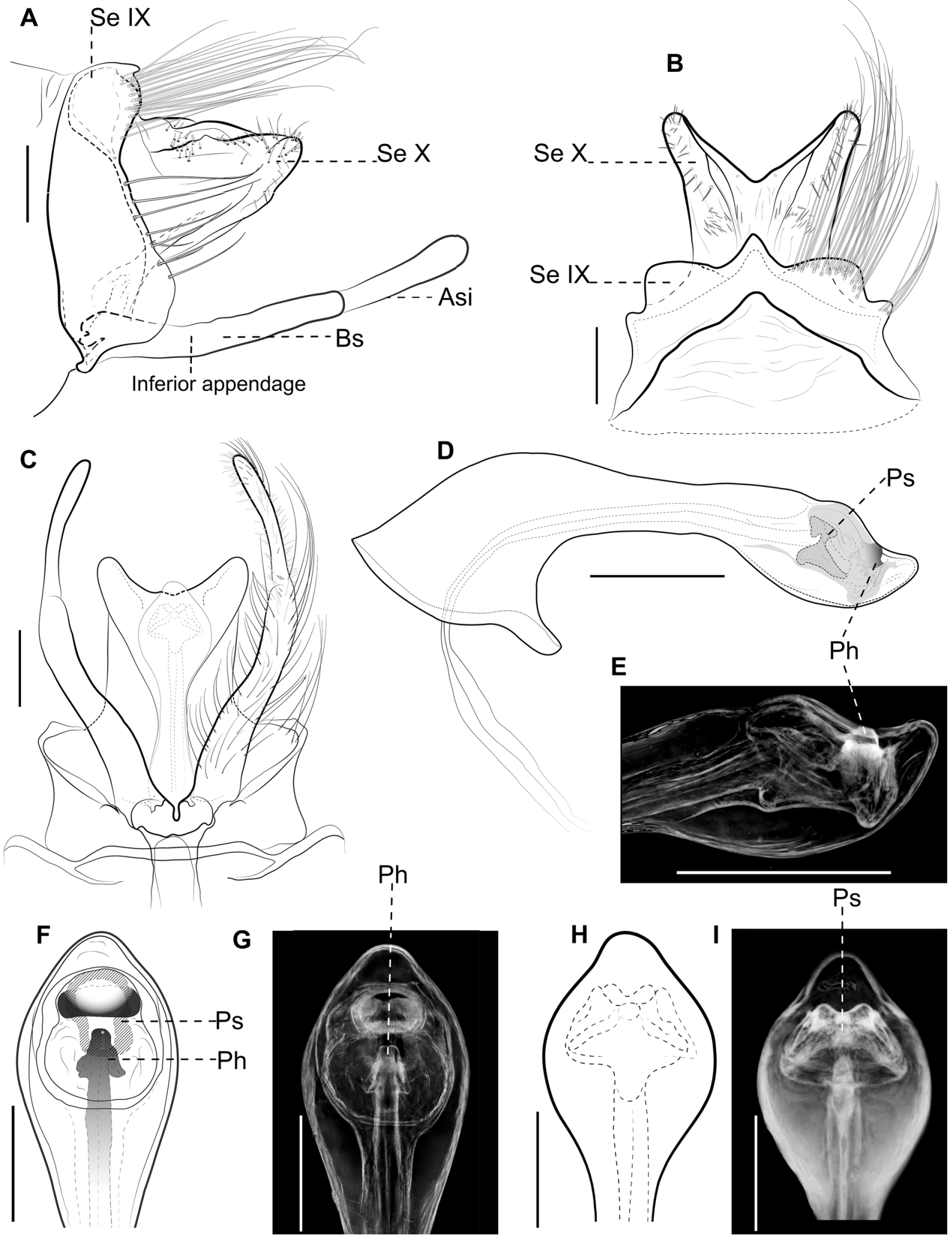

Fig. 3. Macrostemum araca sp. nov., male genitalia. A. Lateral view. B. Dorsal view. C. Ventral view. D-E. Phallus, lateral view. F-G. Phallus, dorsal view. H-I. Phallus, ventral view. Scale bars: A-D = $0.2 \mathrm{~mm} ; \mathrm{E}-\mathrm{I}=0.1 \mathrm{~mm}$. 
Male genitalia. (Fig. 3A-I). Segment IX, in lateral view (Fig. 3A), with anterolateral margin slightly sclerotized and sinuous, delimited by 20 long dorsal setae and 9 scattered setae at ventral half, anterior margin almost straight; in dorsal view (Fig. 3B), posterior margin with triangular median keel, two lateral lobes with cluster of long setae. Segment $X$ in lateral view (Fig. 3A) subtriangular, apex rounded, with subdorsal cluster of small setae near midlength, apex with smalls setae; in dorsal view (Fig. 3B) bilobed, each lobe with thick and short setae, mesal incision wide, forming deep, wide V-shape, reaching half-length of segment X. Inferior appendages, in lateral view (Fig. 3A), two-segmented, basal segment long, apical segment short, about $1 / 3$ of the total length, apex rounded and slightly clavate, covered uniformly by long (external) and short (internal) setae; in ventral view (Fig. 3C) covered uniformly by
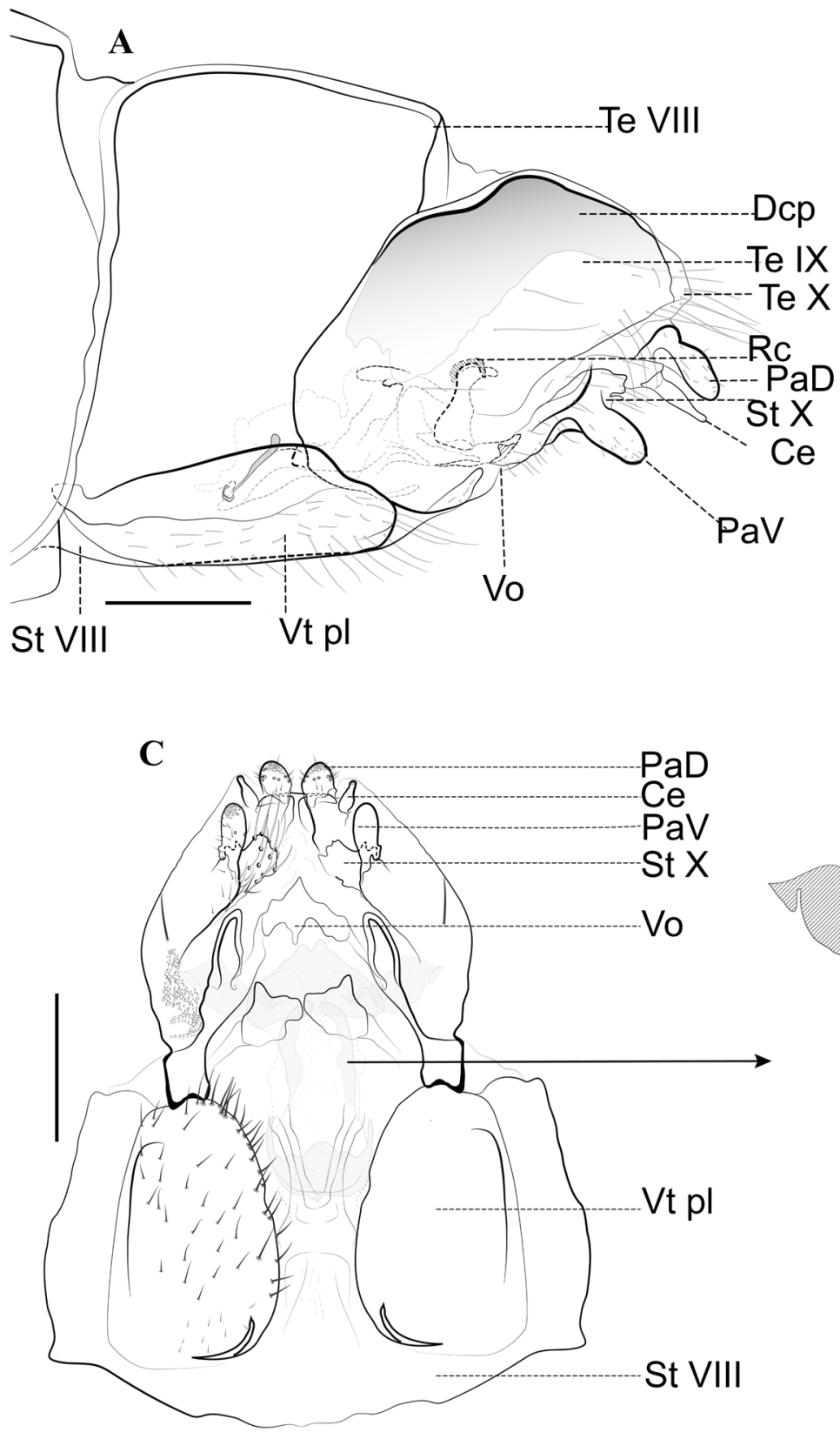

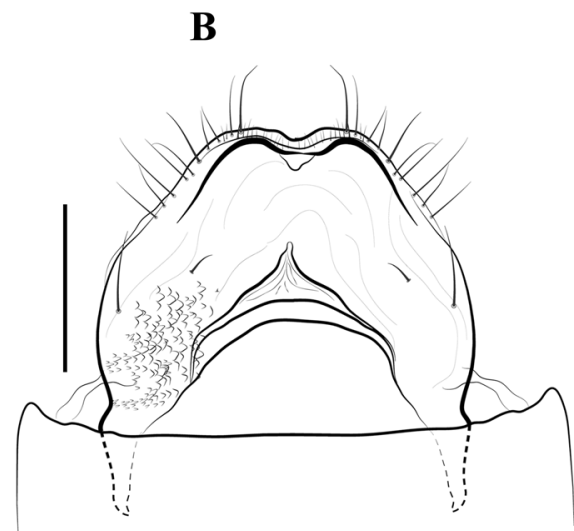

D

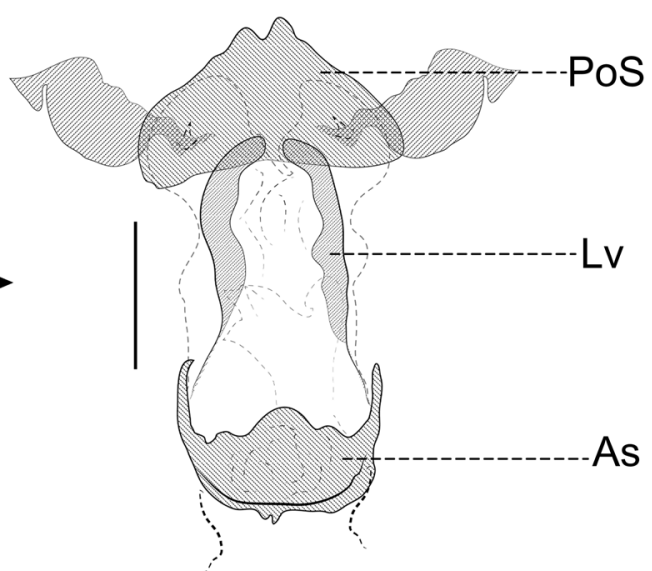

Fig. 4. Macrostemum araca sp. nov., female genitalia. A. Lateral view. B. Dorsal view. C. Ventral view. D. Vaginal apparatus. Scale bars: A-C $=0.2 \mathrm{~mm} ; \mathrm{D}=0.1 \mathrm{~mm}$. 
long (external) and short (internal) setae. Phallus tubular, with apex dilated, forming long acuminate posterolateral prominence (Fig. 3D-I); in ventral view (Fig. 3H-I) phallotremal sclerite in shape that resembles a mushroom with 2 small apical lobes, phallotrema arrow-shaped; in dorsal view (Fig. 3F-G) opening of the annular phallotrema dorsally positioned.

\section{Adult female}

Length of forewing: $9.26-11.46 \mathrm{~mm}($ mean $=10.42 \mathrm{~mm}, \mathrm{SD}=0.68, \mathrm{n}=10)$.

General color pattern, tibial formula, and glandular process of sternite $\mathrm{V}$ similar to male, differing only in the posterior setal wart, which is smaller, more triangular and not so prominent. Venation of the fore wing and hindwing similar to that of male, but the anal area of the posterior wing is about $1 / 5$ narrower than the wing of the male.

Female genitalia. (Fig. 4A-D). Sternum VIII divided almost completely along the midline into two plates, each oval-shaped, covered with setae across the surface (Fig. 4A, C). Tergum IX anterior region with reticulated cuticle, similar to an irregular honeycomb, each cell with 3 to 4 short setae; in lateral view, apex with small setae; in dorsal view (Fig. 4B), posterior margin with a row of long setae. Tergum $\mathrm{X}$ small and narrow, almost entirely covered by tergum IX (Fig. 4A, C). Sternum X ending with 2 pairs of distinct papillae; a pair of biarticulated cerci positioned between the papillae in ventral and lateral views (Fig. 4A, C). Internal vaginal apparatus complex, with posterior sclerite triangular, anterior sclerite annular, wider in the median region, with two lateral projections, lateral valve long and narrow, rod-shaped (Fig. 4D).

\section{Immature stages \\ Unknown.}

\section{Taxonomic remarks}

Female genitalia of the Neotropical Macrostemum species have not been described or illustrated, so we cannot compare this structure with other species from the region. Some species from the Oriental Region have female genitalia illustrated and described (Hoang et al. 2005). The oval-shaped ventral plate of sternum VIII is somewhat similar to that of M. floridum Navás, 1929, but in M. araca sp. nov. it is broader at the base, and the ventral and dorsal papillae are more dilated.

\section{Bionomics}

This species was collected in the Rio Aracá (a large river, with 200-250 m of the width) (Fig. 5E) and in some of its small tributaries (with $1-5 \mathrm{~m}$ of the width), all with black water, in a forested area (Fig. 5CD) located at the base of the Serra do Aracá, in the Brazilian Amazon (Fig. 5A).

\section{Distribution}

Brazil (Amazonas).

Macrostemum brasiliense (Fischer, 1970)

Figs 5-9

Macrostemum brasiliense (Fischer, 1970): 242 [nomen novum for Phryganea maculata Perty, 1833, preoccupied in Phryganea by Phryganea maculata Donovan, 1813, which is now a synonym of Hydropsyche instabilis (Curtis, 1834)]. — França et al. 2013: 309 [ô; wings; status]. — Paprocki \& França 2014: 29 [checklist]. — Holzenthal \& Calor 2017: 154 [catalog].

Phryganea maculata - Perty 1833: 129 [Type locality: Brazil, inter St. Pauli civitatem et Villam riccam; ZSM; $\left.{ }^{\Uparrow}\right]$. 


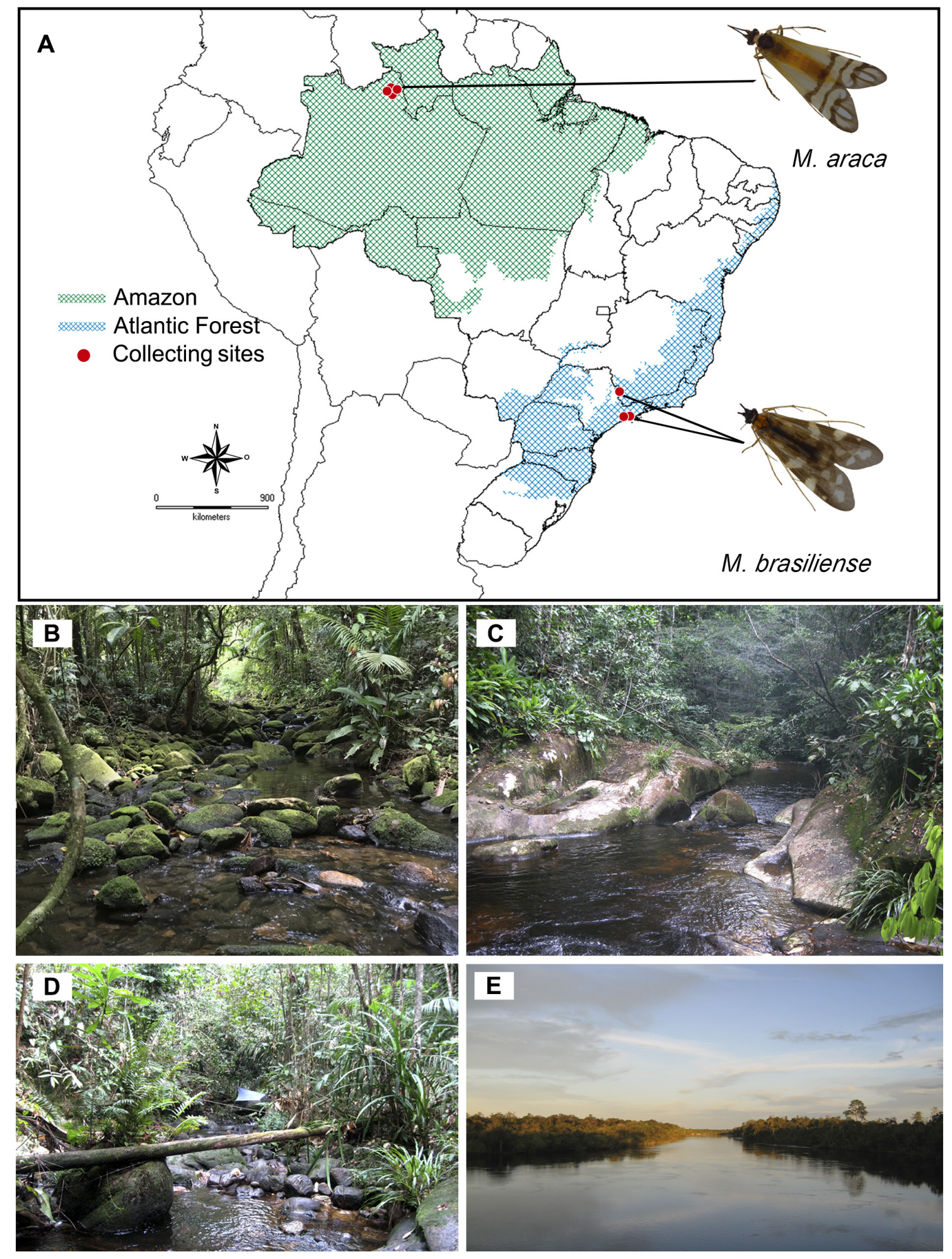

Fig. 5. Collection sites of Macrostemum araca sp. nov. and Macrostemum brasiliense (Fischer, 1970) and general views of some of the sampled streams and rivers. A. A map showing the collection sites of M. araca sp. nov. and M. brasiliense in the Amazon and Atlantic Forest, respectively. B. Córrego (stream) Venerando, São Paulo, collection site of M. brasiliense. - C-E. collection sites of M. araca sp. nov. C. Igarapé da (stream) Cobra, Amazonas. D. Igarapé (stream) do Jabuti, Amazonas. E. Rio (river) Aracá, Amazonas. 
Macronema tuberosum - Ulmer 1905: 82 [Type locality: Bahia, Brasilia; NMW; đ̊; wings]. — Ulmer 1907a: 78, pl. 3 [0̄; wings]. — Ulmer 1907b: 165 [distribution]. — Flint 1966: 7, pl. 1 [lectotype; O’; wings]. — Ulmer 1913: 408 [distribution]. — Fischer 1963: 199 [bibliography, checklist]. — Burmeister 1983: 273 [to synonym of Macronema maculatum].

Macronema maculatum - Ulmer 1907a: 79, pl. 3 [wings; + +]. — Ulmer 1913: 395 [ð̊; distribution]. — Fischer 1963: 190 [bibliography]. — Flint \& Bueno-Soria 1982: 358 [to Macrostemum]. — Burmeister 1983: 273 [type situation]. — Burmeister 1989: 259 [lectotype; $\widehat{~}$ ].

Macrostemum maculatum - Flint et al. 1999: 68 [catalog]. — Paprocki et al. 2004: 8 [checklist]. — Calor 2011: 321 [checklist]. — Barcelos-Silva et al. 2012: 1278 [distribution]. — Dumas \& Nessimian 2012: 13 [checklist]. — França et al. 2013: 309 [to synonymy].

\section{Material examined}

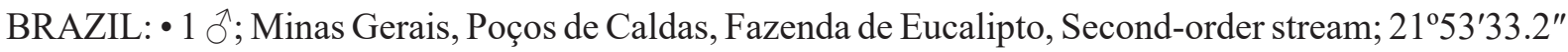
S, 463'03.8" W; alt. 1327 m; 14-15 Sep. 2017; G.R. Desidério, E.P. Brandão and L.M. Fusari leg.; INPA • 10 larvae, 1 pharate pupa đ̃; São Paulo, Salesópolis, Estação Biológica Boracéia, Córrego Venerando; 2339'04.7" S, 4553'28.3" W; alt. 864 m; 22 Sep. 2017; G.R. Desidério, E.P. Brandão

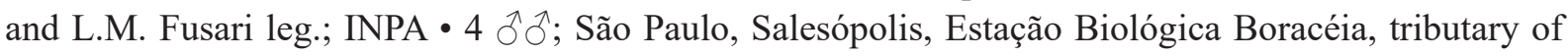
the Córrego Venerando stream; 2339'13.2" S, 4553'24.4" W; 20-22 Sep. 2017; G.R. Desidério, E.P. Brandão and L.M. Fusari leg.; INPA.

\section{Description}

Larva ( ( $^{\text {th }}$ instar) (Figs 6-8)

Length 19.6-21.2 $\mathrm{mm}($ mean $=20.3 \mathrm{~mm}, \mathrm{SD}=0.66 \mathrm{~mm}, \mathrm{n}=5)$.

HEAD. Subrectangular and flattened in dorsal view, with anterior margin $1.5 \times$ wider than posterior margin (Fig. 6A); dark-brown except for darker anterodorsal region; each stemmata surrounded by a pale-yellow oval spot; muscle scars inconspicuous. Dorsolateral carina prominent passing above eyes, extending to posterior region, diverging from the frontoclypeal suture (Fig. 6A, C). Chaetotaxy consisting of \#2, \#3, \#7, \#9, \#11,\#13,\#14, \#16, \#17 [dorsal setae], \#12 [lateral setae], \#8, \#10 [ventral setae]. Primary setae mostly long, thick and pale brown (Fig. 6A-C). Frontoclypeus with anterior margin straight, symmetrical (Fig. 6A). Labrum golden-brown, with large membranous basal region bearing 2 transverse sclerites adjacent to frontoclypeus; anterior margin protruding medially, with dense fringe of pale-yellow, hairlike setae over its entire length and a row of short, brown clavate setae; laterally with a pair of pectinate brushes of setae, long, yellowish-brown and anteriorly directed; mesodorsally surface with short, stout brown setae and one pair of long, parallel, submarginal setae (Fig. 6E). Mandibles asymmetrical, each external margin with pale, long, thin setae; left mandible with 1 obtuse molar tooth, 1 bilobed, mesal tooth, 2 subequal acute subapical teeth, 1 acute, apical tooth, 1 apicodorsal tooth; right mandible with 1 obtuse molar tooth, 1 obtuse mesal tooth, 1 obtuse subapical tooth, 1 acute apical tooth, 1 apicodorsal tooth; both mandibles without dorsomesal tuft of thin setae (Fig. 6F). Lateral sides of head with series of pale-brown muscle scars located posteriorly to occipital margin at posterior tentorial pit (Fig. 6C). Genae located ventrally, each with conspicuous patch of strongly marked, transverse stridulatory lines; widely separated at $1 / 3$ anterior, gradually turning more closely-spaced posteriorly; pale-brown mark covering stridulatory lines and slightly narrowing to posterior region; muscle scars oval and pale grouped on posterior half and scarcely discernible (Fig. 6B, D). Submentum trapezoidal, large; anterior margin slightly accentuated medially, with long, dark anterolateral setae (Fig. 6B). Ventral ecdysial suture absent anteriorly on the right side; anterior ventral apotome subtriangular, wider than long; posterior ventral apotome triangular, minute, longer than wide (Fig. 6D). 

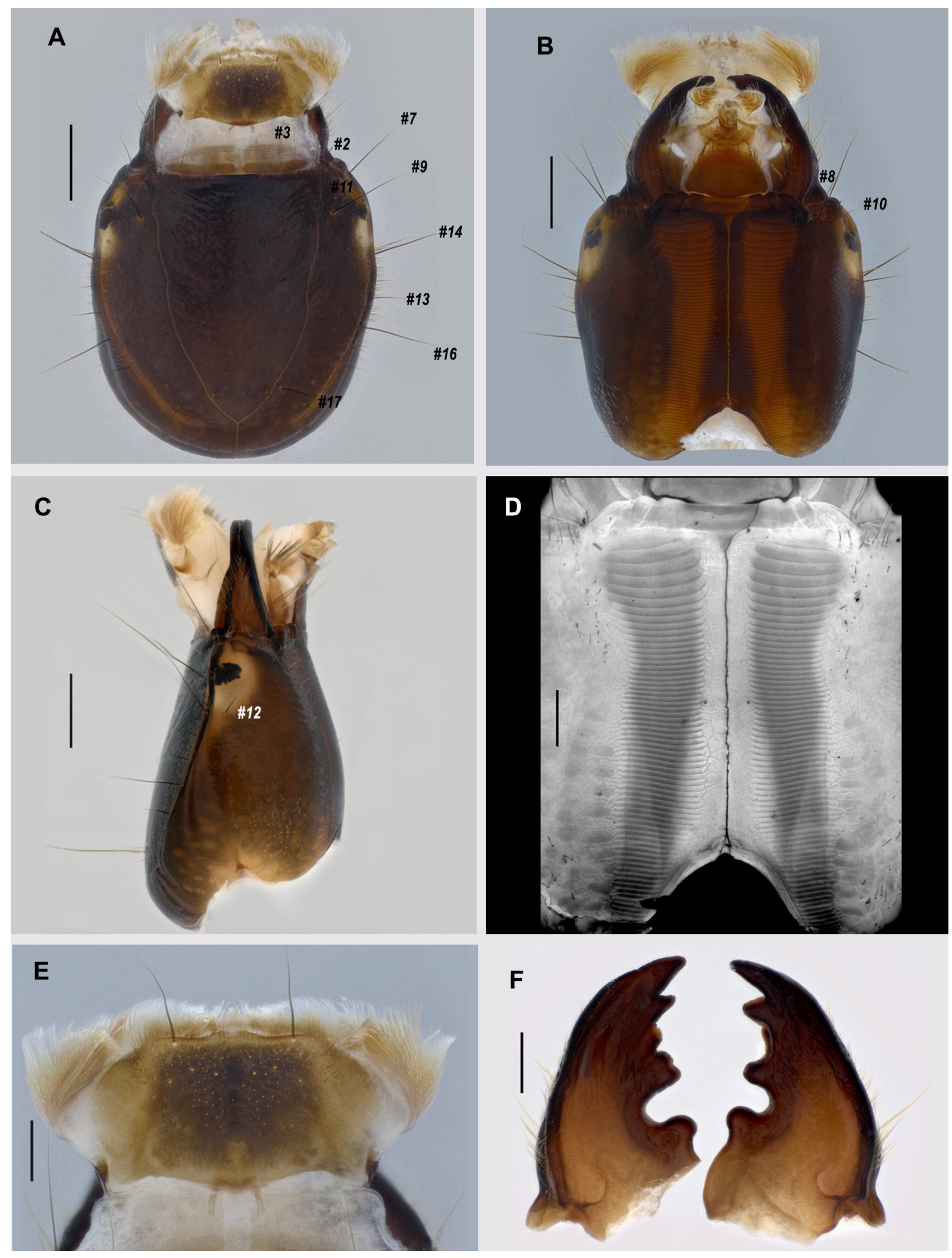

Fig. 6. Macrostemum brasiliense (Fischer, 1970), larva. A. Head, dorsal view. B. Head, ventral view. C. Head, left lateral view. D. Stridulatory lines of genae, ventral view. E. Labrum, dorsal view. F. Mandibles, dorsal view. Scale bars $=0.2 \mathrm{~mm}$. 

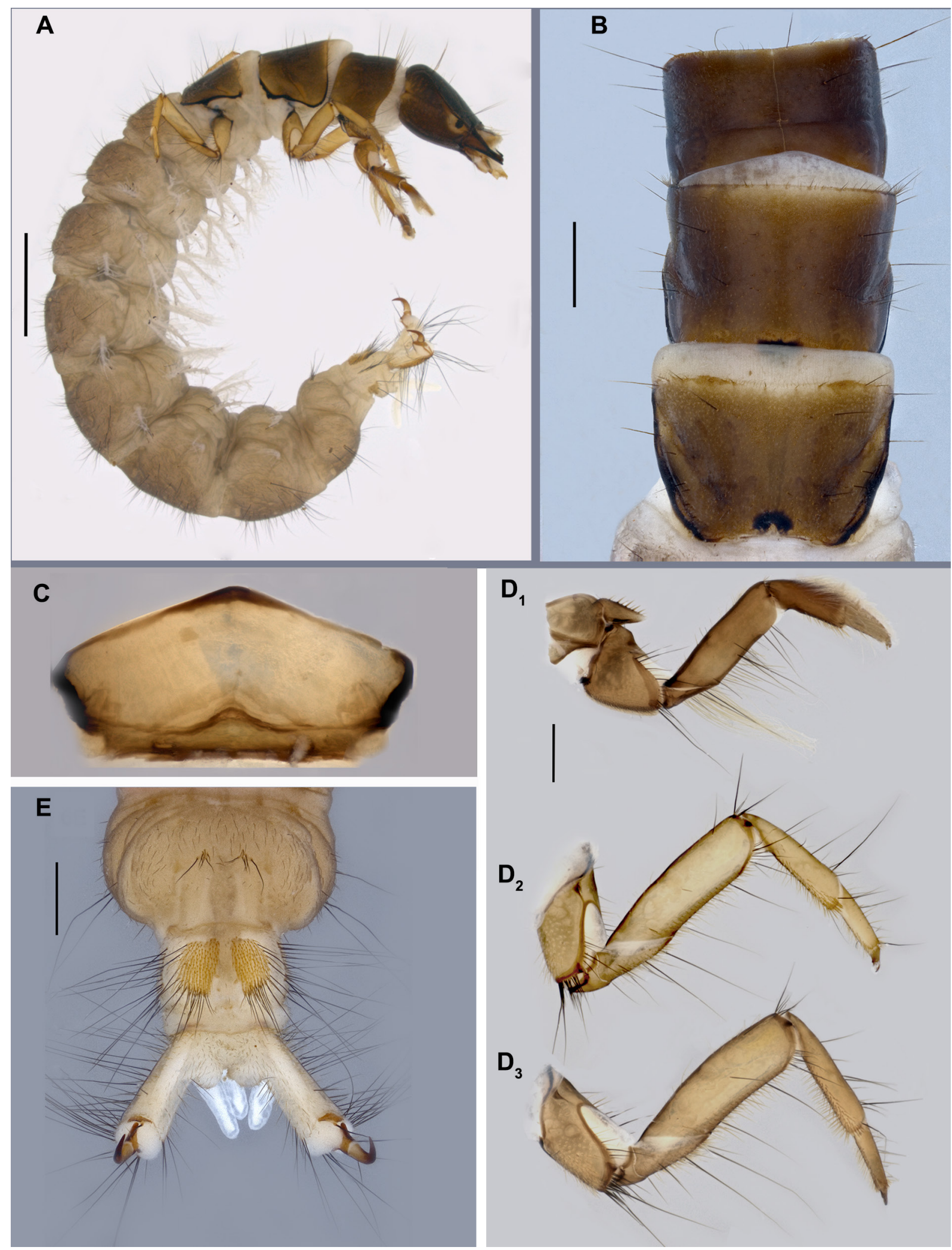

Fig. 7. Macrostemum brasiliense (Fischer, 1970), larva. A. Larval habitus. B. Thoracic nota, dorsal view. C. Prosternum sclerite. $\mathbf{D}_{1}$. Foreleg. $\mathbf{D}_{2}$. Midleg. $\mathbf{D}_{3}$. Hindleg. E. Sternum VIII, IX and anal prolegs, ventral view. Scale bars: $A=1 \mathrm{~mm} ; \mathrm{B}=0.5 \mathrm{~mm} ; \mathrm{D}_{1}-\mathrm{D}_{3}, E=0.2 \mathrm{~mm}$. 
THORAX. Nota sclerotized and covered with short, thin, brown, acuminate peg-like setae, mixed with long, slender, hair-like setae. Pronotum divided by longitudinal ecdysial line, dark-brown, muscle scars barely visible, grouped posterolaterally and with anterolateral pronotal margin slightly concave (Fig. 7A-B). Meso- and metanotum not divided by ecdysial lines, pale-brown, darker midlaterally, lateral diagonal grooves slightly visible, muscle scars barely visible, grouped posterolaterally (Fig. 7B). Prosternum without gills, broadly transverse, without triangular, posteromesal sclerite (Fig. 7C); mesosternum without gills; metasternum with 2 pairs of ventrolateral gills, each with long stalk and few regularly distributed lateral filaments (Fig. 8). Foretrochantin triangular, tapered to apex with a row of numerous

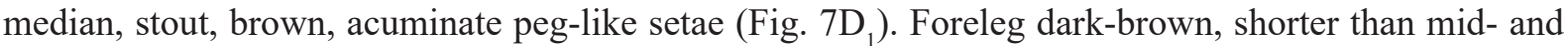
hind legs; foreleg coxae with anterodorsal process slightly pronounced; with four long, dark, thick setae on posterodorsal region, ventral margin covered with numerous short, pale, slender setae and two long dark thick setae posteriorly; trochanters and femora each with numerous pale-yellow, long, slender setae on ventral margin, mixed with row of 11-13 dark, long, slender setae; femora each with slender, digitate basomesal process on internal surface; tibiae and tarsi with dense fringe of pale-yellow, medium-sized, slender setae on dorsal margin and row of thick setae on ventral margin (Fig. $\left.7 \mathrm{D}_{1}\right)$. Mid- and hind legs paler, similar in size, shape, and structure; femora each with numerous medium-sized, pale-yellowish, slender setae on ventral margin, mixed with 4 dark, long, slender setae, and 2 dark, long apicodorsal setae; tibiae and tarsi with numerous medium-sized pale-yellow, slender setae on ventral margin, and dark, long, slender dorsal setae (Fig. $7 \mathrm{D}_{2}-\mathrm{D}_{3}$ ).

AвDomen. Abdominal segments densely covered with long, dark, thin, hair-like setae; with slightly depression on cuticle. Lateral fringe of setae absent (Fig. 7A). Ventral gills on abdominal segments I-VII; ventrolateral gills on abdominal segments II-III; lateral gills on abdominal segments I-VII; shape and position of gills as indicated in table of Figure 8. Sternum VIII with 2 small sclerites; each sclerite with 5-6 medium-sized, dark, slender setae (Fig. 7E). Segment IX with small, dorsolateral plate bearing 2 long, dark, slender setae, and with a row of long, dark setae laterally (Fig. 7A). Sternum IX with 2 subrectangular sclerites, longer than wide, bearing moderate-sized, pale-yellowish, spikelike setae with spines emanating from prominent sockets; each sclerite with 12-14 long slender, dark setae on external and posterior margin (Fig. 7E). Anal prolegs each with lateral sclerite bearing tuft of

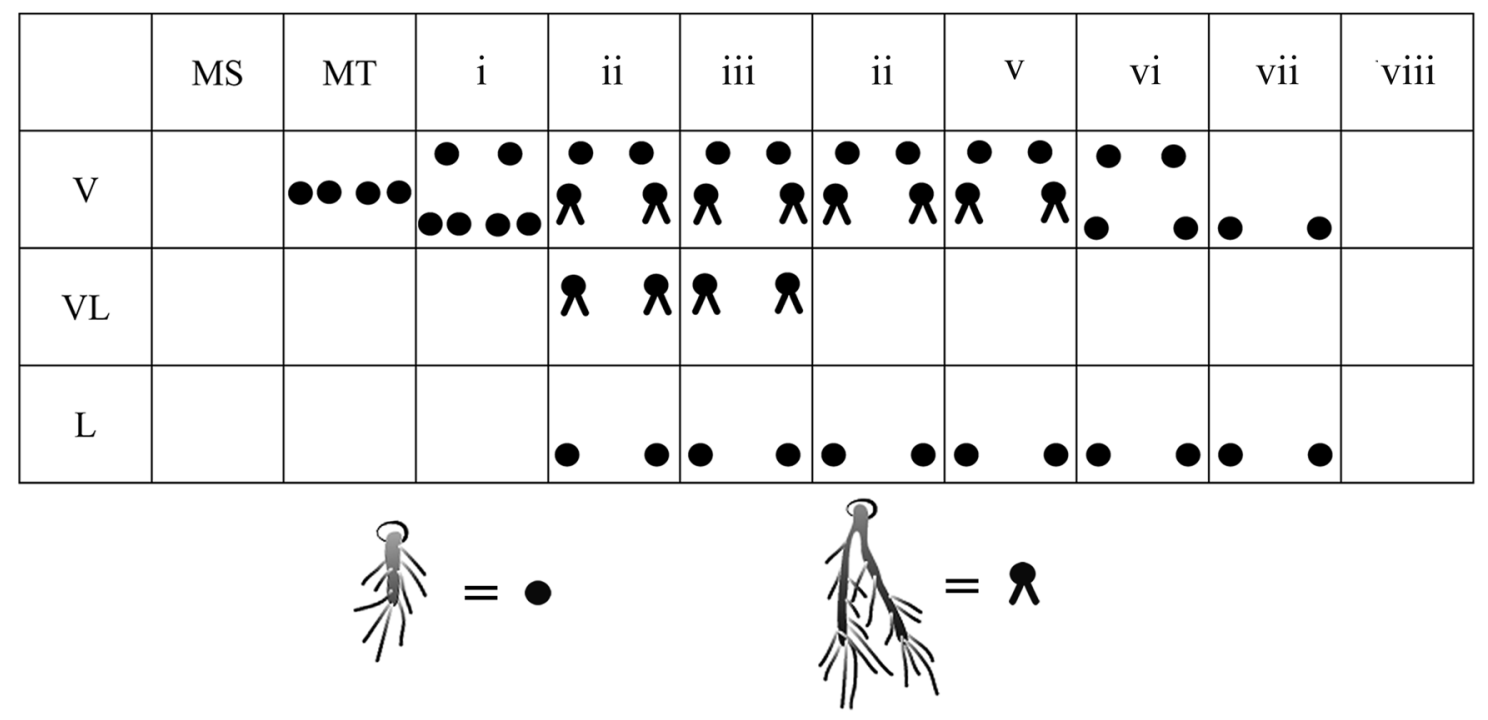

Fig. 8. Macrostemum brasiliense (Fischer, 1970), larva; gill formula (MS = mesothorax; MT = metathorax; $\mathrm{i}-\mathrm{viii}=$ abdominal segments; $\mathrm{V}=$ ventral gills; $\mathrm{VL}=$ ventrolateral gills; $\mathrm{L}=$ lateral gills). 
numerous, long, hair-like dorsal setae; anal claws stout, right-angled, each with 1 bent, simple, long, dark, ventrobasal seta (Fig. 7A, E).

LARVAL RETREAT. The larval retreat of $M$. brasiliense is similar to that of Macrostemum sp. described by Sattler $(1963,1968)$ and illustrated in Pes et al. (2005) from an unidentified species of Brazilian Amazonia, with an elaborate net for fine particle capture.

Pupa (Fig. 9)

Body length $16.7 \mathrm{~mm}(\mathrm{n}=1)$.

HEAD. Labrum with anterior margin rounded; anteromesal region without setae; basolateral lobes each with 2 medium-sized setae (Fig. 9B). Mandibles asymmetrical, broad basally, curved mesally, tapering to apex, each with long setal brush basolaterally; inner margin with acute teeth mesally, 3 on both mandibles, and apical half of mandibles finely serrated (Fig. 9C). Frons faces anteriorly with oval protruding lobe, mesally bilobed bearing 9-11 long, dark setae and one medium-sized seta on each lobe, posteriorly with 8 long, dark setae. Basal antennal article with 5 medium-sized, brown setae (Fig. 9B).

ThORax. Pale yellow, with dark spots laterodorsally. Tibia and tarsus of midleg broad and flattened, with well-developed lateral fringes of setae (Fig. 9A).

AвDOMEN. Numerous moderate-sized, yellowish-brown, spike-like setae covering abdominal terga II, III on its posterior portion, and a file of long, thin, dark, hair-like setae on tergum IV in its entire posterior portion (Fig. 9A). Lateral fringe absent. Abdominal terga with pairs of anterior hook plates (a) on segments III-VIII with hooks directed posterad; pair of posterior hook plates (p) on segment III with hooks directed anterad; hook-plate pair IIIa with 2-3 pointed, stout hooks; hook-plate pair IIIp with 56-60 sharply pointed, small hooks; hook-plate pair IVa each with 2 pointed, stout hooks; hook-plate pair Va with 2 pointed, stout hooks and 1-2 mesal, smaller; hook-plate pair VIa each with 1 bifid hook, 1 pointed, stout hook and 1 minute; hook-plate pair VIIa with 2 pointed, stout hooks and 1 smaller; hook-plate pair VIIIa each with 2 pointed, stout hooks (Fig. 9D). Apical processes of segments IX-X long, slender, widely separated, each with 23-24 long lateral, setae on external margin and 6-9 long subapical setae on internal margin (Fig. 9E).

PUPAL RETREAT. Inside the larval retreat, the $5^{\text {th }}$ instar constructs a tubular case of resistant sand covered with silk, with a small opening in the posterior region; in the anterior region the opening is closed with a cover of sand where the larva weaves the pupal cocoon, it is similar to that of the Amazonian undetermined species described by Sattler (1963).

\section{Taxonomic remarks}

In the larval stage, M. brasiliense is similar to M. ulmeri by the prominent dorsolateral carina extending to posterior region, diverging from the frontoclypeal suture. Both can be distinguished from other species in the genus with known immatures like the Nearctic M. carolina (Banks, 1909), M. transversum (Walker, 1852) and M. zebratum (Hagen, 1861), which have carina closed passing over the posterior region from the frontoclypeal suture. Additionally, M. brasiliense is characterized by the dark-brown head with darker anterodorsal region; frontoclypeus with anterior margin straight; left mandible with 1 obtuse molar tooth and 1 bilobed mesal tooth; right mandible with 1 obtuse mesal tooth and 1 obtuse subapical tooth; genae with transverse stridulatory lines widely separated at anterior $1 / 3$, transition to closely-spaced posterior lines gradual; submentum with anterior margin convex with slight projection medially, with long, dark anterolateral setae; mesosternum without gills; foreleg coxae with anterodorsal process slightly pronounced; ventral gills on abdominal segments I-VII, ventrolateral gills on abdominal segments II-III and lateral gills on abdominal segments I-VII. 

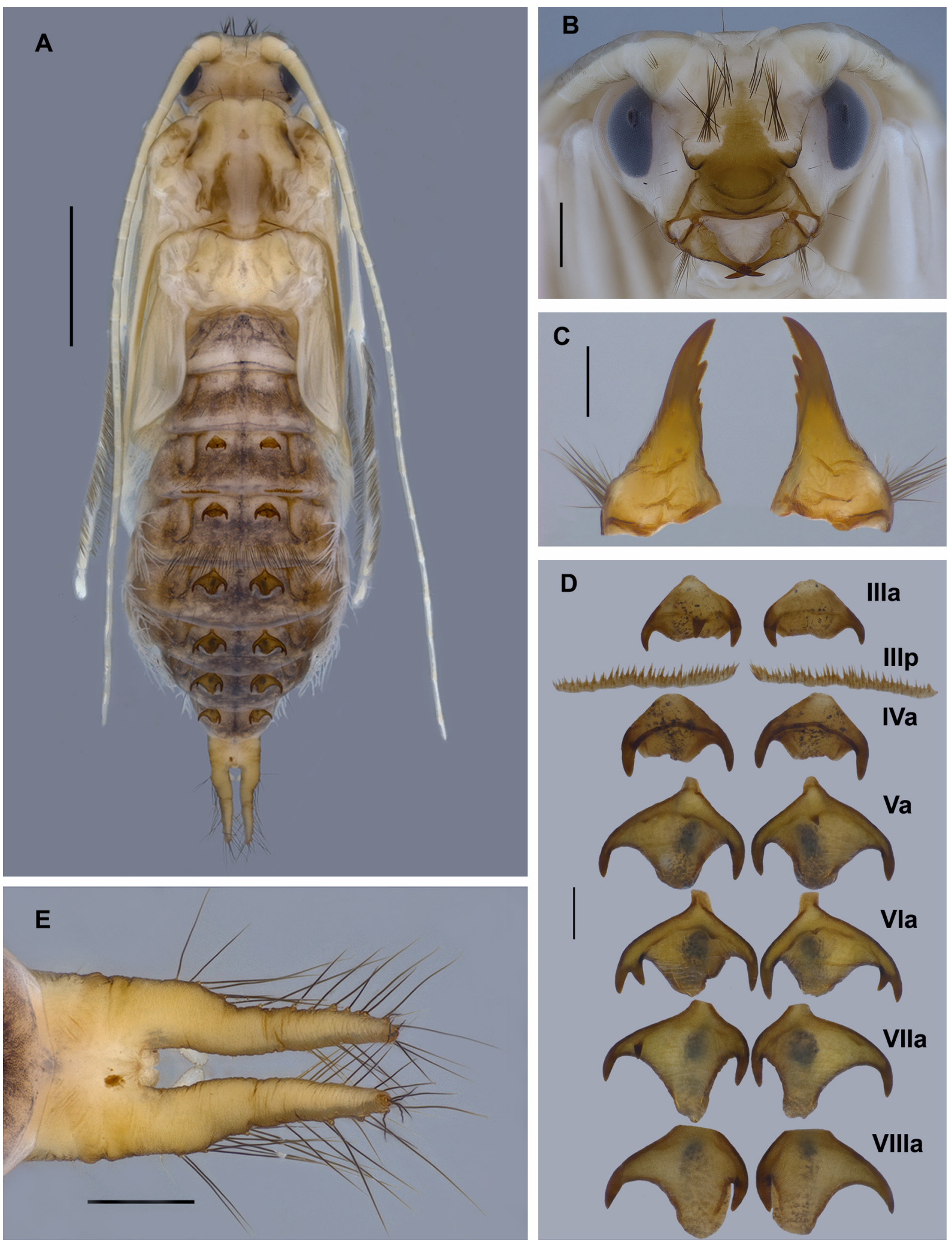

Fig. 9. Macrostemum brasiliense (Fischer, 1970), pupa. A. Pupal habitus, dorsal view. B. Head, frontal view. C. Mandibles, dorsal view. D. Hook plates, dorsal view (III-VIII = abdominal segments, a = anterior, $\mathrm{p}=$ posterior). E. Abdominal segments IX-X, dorsal view. Scale bars: $\mathrm{A}=2 \mathrm{~mm} ; \mathrm{B}, \mathrm{E}=$ $0.05 \mathrm{~mm} ; \mathrm{C}-\mathrm{D}=0.2 \mathrm{~mm}$. 
The pupa of M. brasiliense is similar to that of M. ulmeri by abdominal terga with pairs of anterior hook plates on segments III-VIII, with stout hooks directed posteriorly, and pair of posterior hook plates on segment III with hook directed anteriorly. However, M. brasiliense has hook-plate pair IIIa and IVa each with 2-3 and 2 pointed hooks, respectively, and 56-60 sharply pointed, small hooks directed anteriorly of the posterior hook plates, while M. ulmeri has 3 pointed hooks on each hook-plate pair IIIa and IVa and $23-35$ sharply pointed, small hooks on posterior hook plates.

\section{Bionomics}

This species is commonly found in Brazilian Atlantic Forest (Santos et al. 2018). In the present study it was collected in small mountain streams in rain forest reserve (Estação Biológica de Boracéia) in Salesópolis municipality, São Paulo state, at an elevation of $864 \mathrm{~m}$ a.s.l. (Fig. 5A-B) and in an extensive area with Eucalyptus spp. (Myrtaceae) plantations, in Poços de Caldas municipality, Minas Gerais state, at an elevation of $1327 \mathrm{~m}$ a.s.l. (Fig. 5A).

\section{Distribution}

Brazil (Bahia, Minas Gerais, Rio de Janeiro, and São Paulo states).

\section{Discussion}

Macrostemum now includes 19 species for the Neotropical region, which are mainly diagnosed by the wing color patterns. However, França et al. (2013) found that this character usually shows some intraspecific variation and observed that the shape of the phallotremal sclerite, in ventral view, is also a useful character for identifying species of Macrostemum. In addition, characters of the female genitalia may also be useful for distinguishing species in the genus, as observed in the case of M. araca sp. nov. when compared to the few other species in the genus that have their females associated and described.

Despite the high diversity of Macrostemum in the tropics (Morse 2019), little is known about the immature stages. To date, M. brasiliense is only the second species in the Neotropical region that is accurately associated, and with its immature stages described and illustrated.

Therefore, based on the poor knowledge about female genitalia and larval and pupal characters of Macrostemum species, we recommend more studies associating adult females and immatures stages. Studying the morphology of these life stages may help in the delimitation of the species, as well as providing a source of morphological characters for phylogenetic studies and for biomonitoring of aquatic environments.

\section{Acknowledgments}

We thank Mireile R. dos Santos and Vinicius Puerta Ramos for the advice, infrastructure, and transportation that allowed the fieldwork to be done in Poços de Caldas. We are also grateful to Lívia M. Fusari and Evelyn P. Brandão for their friendship and valuable assistance in the fieldwork. Financial support was provided by the following projects: Sistemática Integrada de Insetos Aquáticos, com Ênfase em Simuliidae (Diptera) na América do Sul (MCTIC/INPA), Insetos Aquáticos da América do Sul (CNPq), and CAPES/Pro-Equipamentos-DCEN. AMP received post-doctoral fellowships from FIXAM/ FAPEAM/AM (Process n. 062.02520/2014), PCI/INPA (Process n. 314034/2017-0) and PDS/CNPq (Process n. 165223/2017-0). CNPq provided a doctoral fellowship for GRD (Process n. 141875/20186) and PBS, and a research fellowship for NH (Process n. 307849/2014-7). Instituto Chico Mendes de Conservação da Biodiversidade (ICMBio) for issuing collecting permits (Proc. 12986-1, 243032, 59800-1 and 60207-1). Thanks to Philip M. Fearnside, who reviewed this manuscript. We highly appreciate the valuable comments and corrections of the two anonymous reviewers on our manuscript. 


\section{References}

Barcelos-Silva P., Pes A.M.O. \& Salles F.F. 2012. Annulipalpia (Insecta: Trichoptera) from the state of Espírito Santo, Brazil. Check List 8 (6): 1274-1279. https://doi.org/10.15560/8.6.1274

Brown B.V. 2013. Automating the 'Material Examined' section of taxonomy papers to speed up species descriptions. Zootaxa 3683 (3): 297-299. https://doi.org/10.11646/zootaxa.3683.3.8

Burmeister E.G. 1983. A preliminary study on some groups of insects collected by Spix and Martins during their Brazilian expedition, which were described by Perty and are preserved in the Zoologische Staatssammlung, Munich (ZSM). Spixiana 9: 265-281.

Burmeister E.G. 1989. Der Lectotypus von Macronema maculatum (Perty 1833) (Trichoptera, Hydropsychidae). Spixiana 11: 259-262.

Calor A.R. 2011. Checklist of Trichoptera (Insecta) from São Paulo State, Brazil. Biota Neotropica 11: 317-328. https://doi.org/10.1590/S1676-06032011000500028

Dumas L.L. \& Nessimian J.L. 2012. Faunistic catalog of the caddisflies (Insecta: Trichoptera) of Parque Nacional do Itatiaia and its surroundings in southeastern Brazil. Journal of Insect Science 12 (1): 1-38. https://doi.org/10.1673/031.012.2501

Fischer F.C.J. 1963. Trichopterorum Catalogus. Vol. 4: Hydropsychidae, Arctopsychidae. Nederlandsche Entomologische Vereeniging, Amsterdam.

Fischer F.C.J. 1970. Trichopterorum Catalogus. Vol. 11: Philanisidae, Lepidostomatidae, Brachycentridae, Beraeidae, Sericostomatidae, Thremmatidae, Helicopsychidae. Nederlandsche Entomologische Vereeniging, Amsterdam.

Flint O.S. Jr. 1966. Studies of Neotropical Caddisflies, III: Types of some Species Described by Ulmer and Brauer. Proceedings of the United States National Museum 120: 1-20.

https://doi.org/10.5479/si.00963801.120-3559.1

Flint O.S. Jr. 1978. Studies of Neotropical Caddisflies, XXII: Hydropsychidae of the Amazon Basin (Trichoptera). Amazoniana 6: 373-421.

Flint O.S. Jr. \& Bueno-Soria J. 1982. Studies of Neotropical Caddisflies, XXXII: The immature stages of Macronema variipenne Flint \& Bueno, with the division of Macronema by the resurrection of Macrostemum (Trichoptera: Hydropsychidae). Proceedings of the Biological Society of Washington 95 (2): $358-370$.

Flint O.S. Jr., Holzenthal R.W. \& Harris S.C. 1999. Catalog of the Neotropical Caddisflies (Trichoptera). Special Publication, Ohio Biological Survey, Columbus.

Flint O.S. Jr. \& Wallace J.B. 1980. Studies of Neotropical Caddisflies, XXV: The immature stages of Blepharopus diaphanus and Leptonema columbianum (Trichoptera: Hydropsychidae). Proceedings of the Biological Society of Washington 93 (1): 178-193.

França D., Paprocki H. \& Calor A.R. 2013. The genus Macrostemum Kolenati 1859 (Trichoptera: Hydropsychidae) in the Neotropical Region: Description of two new species, taxonomic notes, distributional records and key to males. Zootaxa 3716: 301-335.

https://doi.org/10.11646/zootaxa.3716.3.1

Hoang D.H., Tanida K. \& Bae Y.J. 2005. Records of the Vietnamese Macronematinae (Hydropsychidae, Trichoptera) with description of a new species. In: Tanida K. \& Rossiter A. (eds) Proceedings of the $11^{\text {th }}$ International Symposium on Trichoptera: 63-71. Tokai University Press, Kanagawa.

Holzenthal R.W. \& Calor A.R. 2017. Catalog of the Neotropical Trichoptera (Caddisflies). ZooKeys 654: 1-566. https://doi.org/10.3897/zookeys.654.9516 
PES A.M. et al., New species and immature stages of Macrostemum from Brazil

Kawada R. \& Buffington M.L. 2016. A scalable and modular dome illumination system for scientific microphotography on a budget. PLoS ONE 11 (5), e0153426. https://doi.org/10.1371/journal. pone. 0153426

Lepneva S.G. 1970. Fauna of the USSR, Trichoptera II (1). Larvae and pupae of the Annulipalpia. Zoological Institute of the Academy of Science of the USSR, New Series 88: 1-638.

Marlier G. 1964. Trichoptères de l'Amazonie recueillis par le Professeur H. Sioli. Memoires l'Institut Royal des Sciences Naturelles de Belgique, series 2 76: 1-167.

Milne M.J. 1938. The 'metamorphotype method' in Trichoptera. Journal of the New York Entomological Society 46 (4): 435-437.

Morse J.C. 2019. Trichoptera World Checklist.

Available from http://entweb.sites.clemson.edu/database/trichopt/index.php [accessed 10 Jan. 2019].

Ogbogu S.S. \& Adu W.B. 2006. First record of Macrostemum alienum Ulmer 1907 (Trichoptera: Hydropsychidae: Macronematinae) from Ile-Ife, Southwestern Nigeria, West Africa. Biota Neotropica 6 (3): 1-7. http://doi.org/10.1590/S1676-06032006000300016

Oláh J. \& Johanson K.A. 2012. New species and records of Neotropical Macronematinae and Smicrideinae (Trichoptera: Hydropsychidae). Annales Historico-Naturales Musei Nationalis Hungarici 104: 215-297.

Paprocki H. \& França D. 2014. Brazilian Trichoptera Checklist II. Biodiversity Data Journal 2: e1557. https://doi.org/10.3897/BDJ.2.e1557

Paprocki H., Holzenthal R.W. \& Blahnik R.J. 2004. Checklist of the Trichoptera (Insecta) of Brazil I. Biota Neotropica 4 (1): 1-22. https://doi.org/10.1590/S1676-06032004000100008

Perty M. 1833. Insecta brasiliensia. In: Perty M. (ed) Delectus animalium articulatorum quae ex itinere per Brasiliam, annis MDCCCXVII-MDCCCXX jussu et auspiciis Maximiliani Josaephi I. Bavariae Regis augustissimi peracto collegerunt Dr. J. B. de Spix et Dr. C. F. Ph. De Martius: 125-224. Friedrich Fleischer, München [Monachii].

Pes A.M.O., Hamada N. \& Nessimian J.L. 2005. Chaves de identificação de larvas para famílias e gêneros de Trichoptera (Insecta) da Amazônia Central, Brasil. Revista Brasileira de Entomologia 49 (2): 181-204. https://doi.org/10.1590/S0085-56262005000200002

Ross H.H. 1944. The caddis flies, or Trichoptera, of Illinois. Illinois Natural History Survey Bulletin 23: $1-326$.

Santos A.P.M., Dumas L.L., Pes A.M.O, Calor A.R., Souza W.R.M., Henriques-Oliveira A.L. \& Camargos L.M. 2018. Trichoptera in Catálogo Taxonômico da Fauna do Brasil. PNUD.

Available from http://fauna.jbrj.gov.br/fauna/faunadobrasil/278 [accessed 14 Feb. 2018].

Sattler W. 1963. Über die Körperbau die Ökologie und Ethologie der Larve und Puppe von Macronema Pict. (Hydropsychidae), ein als Larve sich von 'Mikro-Drift' ernährendes Trichopteraus dem Amazonasgebiet. Archiv für Hydrobiologie 59 (1): 26-60.

Sattler W. 1968. Weitere Mitteilungen über die Ökethologie einer neotropischen Macronema-Larve (Hydropsychidae, Trichoptera). Amazoniana 1 (3): 211-229.

Schefter P.W. \& Wiggins G.B. 1986. A systematic study of the Nearctic larvae of the Hydropsyche morosa Group (Trichoptera: Hydropsychidae). Life Sciences Miscellaneous Publications, Royal Ontario Museum, Toronto. 
Scott K.M.F. 1983. On the Hydropsychidae (Trichoptera) of southern Africa with keys to African genera of imagos, larvae and pupae and species list. Annals of the Cape Provincial Museums (Natural History) 14: $299-422$.

Ulmer G. 1905. Neue und wenig bekannte aussereuropäische Trichopteren, hauptsächlich aus dem Wiener Museum. Annalen des kaiserlich-königlich naturhistorichen Hofmuseums 20: 59-98.

Ulmer G. 1907a. Trichopteren (Monographie der Macronematinae). Collections Zoologiques du Baron Edm. de Selys Longchamps Catalogue Systematique et Descriptif 6 (2): 1-121.

Ulmer G. 1907b. Trichoptera. In: Wytsman P. (ed.) Genera Insectorum: 1-259. Desmet Verteneuil, etc., Bruxelles.

Ulmer G. 1913. Verzeichnis der südamerikanischen Trichopteren, mit Bemerkungen über einzelne Arten. Deutsche Entomologische Zeitschrift: 383-414.

Wiggins G.B. 1996. Larvae of the North American caddisfly genera (Trichoptera), second ed. University of Toronto Press, Toronto.

Williams N.E. \& Wiggins G.B. 1981. A proposed setal nomenclature and homology for larval Trichoptera. In: Moretti G.P. (ed.) Proceedings of the $3^{\text {rd }}$ International Symposium on Trichoptera: 421-429. Dr. W. Junk Publishers, The Hague. https://doi.org/10.1007/978-94-009-8641-1_52

Manuscript received: 19 February 2019

Manuscript accepted: 7 May 2019

Published on: 28 June 2019

Topic editor: Gavin Broad

Desk editor: Radka Rosenbaumová

Printed versions of all papers are also deposited in the libraries of the institutes that are members of the EJT consortium: Muséum national d'Histoire naturelle, Paris, France; Meise Botanic Garden, Belgium; Royal Museum for Central Africa, Tervuren, Belgium; Royal Belgian Institute of Natural Sciences, Brussels, Belgium; Natural History Museum of Denmark, Copenhagen, Denmark; Naturalis Biodiversity Center, Leiden, the Netherlands; Museo Nacional de Ciencias Naturales-CSIC, Madrid, Spain; Real Jardín Botánico de Madrid CSIC, Spain; Zoological Research Museum Alexander Koenig, Bonn, Germany; National Museum, Prague, Czech Republic. 